\title{
慢性腎不全に打孫液凝固能の研究
}

\author{
東京医科菌科大学医学激第二内科（主任武内重五郎教授） \\ 松井 則明
}

\section{BLOOD COAGULABILITY IN CHRONIC RENAL FAILURE}

\author{
Noriaki MATsuI, MD
}

The Second Department of Internal Medicine, Tokyo Medical and Dental University

\begin{abstract}
概要 尿毒淀に和ける凝固能巽常の機序を明らかにするために，保存期腎不全 (N-HD) $(\mathrm{n}=31)$ 拉 よび透析期腎不全 (HD) $(n=28)$ 両群に执いてて種々の凝固関連示標を测定した．正常対照群と比較 し，N-HDではAPTT，トロンボェラストグラフ (TEG)-r, -kが有意に短縮していた。またTEG-ma， フィブリノゲン (Fbg)，第VII，VII， IX，奴因子活性，第怆因子様抗原（VIIIAN），高分子キニノゲン (HMWK)，FDP， $\alpha_{2}$ マクロダロブリン, C1インヒビター (C1 INH)，高分子フィブリ/ゲン複合体 (HMWFC) が有意任增加していた。またエタノールゲル化試験 (EG)，連続希釈酼酸プロタミン試 駼 (SDPS) の陽性率が高かつた. N-HDに拈いてはHDと比較してもTEG-r，-kが短縮して括り，Fbg, TEG-ma，VIIAGN，Cl INH，FDPの增加が認められた。 HDでは正常対照群に比しTEG-r, kが短縮 し， Fbg, 第VII, VII， IX，XI因子活性，VIIAGN，Cl INH，FDP，HMWFCの增加が認められた，EG，SDPS

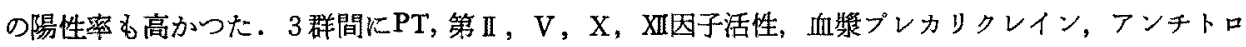
ンビン関する有意差は認められなかった，以上のことから尿毒症においては過疑固状態にあり， 透析に上り部分的に改善する。この過凝固状熊はHMWK, VIIAGNの增加から判断し，血管内皮損第に より内因系凝固機序が活性化されたためではないかと考劣られる。
\end{abstract}

\section{はじめに}

尿毒症とはホメオスターシスの維持に重要な役 割をはたしている緊の機能が廃絶し，そのため多 彩な臨床症状を呈する状態である。その原因とし ては腎の排泄能低下に伴う水・電解質の貯留, 代 謝性アシドーシス, 窒素代謝産物の蓄積などが重 要であるが，カル゙シウム代謝異常，糖代謝異常, 赤血球産生低下などにみられる内分泌異常も軽視 できない，血液凝固線溶系についてもホメオスタ

[昭和55年 1 月 16 日受稿]

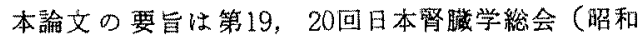
51 年11月 7 日)，(昭和52年 2 月 2 日)，第 6 回血栓 止血に閥する討議会（昭和52年11月12日）および 第76回日本内科学会講演会（昭和54年 4 月 6 日）で 発表した。
ーシスの異常がみられ，線溶能の低下，血小板機 能異常はよく知られているところである. 一方, 内因系, 外因系よりなる凝固能 (以下本論文で凝 固能といつた場合，血小板を除外した液性の凝固 能をさす)については系統的研究は少ないし，あ つてもあるものは光進していると述べ，季た別 のものは低下しているといい(2)，一定の見解が得 られていない。また凝固異常のメカニズムを尿毒 症の本態と結びつけて論したものは少ない，そこ で著者は今回, 凝固能に関して多くのパラメータ 一を使用して多方面より系統的検討を加えた。兵 の結果若干の知見を得たので報告する.

\section{I. 対象および方法}

1) 対象

透析導入直前で尿毒症状態にある慢性腎不全 
患者 (non-hemodialyzed chronic renal failure; 以下non-HDCRF) 31名, 透析導入後 6 力月以上 を経過し安定した状態にある患者 (hemodialyzed chronic renal failure; 以下HDCRF) 28名であ る. 透析患者は 1 回 $4 \sim 6$ 時間の血液透析を週 3 回うけている.SLE腎症, 糖尿病性腎症など全 身性疾患に伴亏腎不全は，その疾患自体により凝 固能異常をきたすことが多いので，対象から除外 した，また感染症，肝疾患などの合併症を有する 患者孔同様の理由で除外した．正常対照として， 健常人 36 名 (年令 $18 \sim 51$ 才, 平均年令 41 才; 男 17名，女19名）についても同様の検索をした．採 血は早朝空腹時を原則とし，透析患者について は透析による修飾をさけるため，透析当日の朝 に採血した。抗凝固薬として $3.8 \%$ クエン酸ナト リウム 9 分の 1 容を加克，線溶により強く影響 されるパラコアグレーションテストやfibrinogen/ fibrin degradation products (FDP), high molecular weight fibrinogen complexes (HMWFC) $k つ$ いては，さらに40単位/mlのアプロチニンを加え た、採血器具怙よび保存容器はすべでプラスッ ク製品を用いた，直ちに測定する必要のないるの はー80息にて冷凍保存した。

\section{2) 測定項目および方法}

プロトロンビン時間（秒）（PT）はWarnerRambert社製シンプラスチンを使用し，Quick一 段法で測定した。

活性化部分トロンボプラスチン時間（秒） (APTT) は，Warner-Rambert社製 プラテリンプ ラスアクチベーターを使用して測定した。

トロンボェラストグラフr，k（分）， ma（mm (TEG-r, k, ma) は, Hellige社トロンボエラスト グラフを用い全血法で測定した。

フィブリノゲン (mg/dl) (Fbg) はチロジン法 によつた，第 II $\cdot \mathrm{V} \cdot \mathrm{VII} \cdot \mathrm{VII} \cdot \mathrm{IX} \cdot \mathrm{X} \cdot \mathrm{XI} \cdot \mathrm{XI}$ 因 子凝固活性（\%)（F II $\cdot \mathrm{F} \mathrm{V} \cdot \mathrm{F} \mathrm{VII} \cdot \mathrm{VIIIAHF} \cdot$ F X ・ F X • F XI - F XII) はDade社製の各因子久 そ血浆を用い，F II ・ F V ・ F VII F X はPTを， VIIIAHF・F IX・FXI・FXIIについては
APTTを利用し，いずれる一段法にて測定した. Dade社Auto Fikよる自動分析である.

血浆プレカリクレイン（\%)(PK) は, Pentapharm社の血等カリクレイン用合成発色基質クロ モザイムPKを用いたアミド分解法である゙．す なわち血浆 $0.5 \mathrm{ml}$ k0.2Mイプシロンアミノカプ ロン酸 (EACA；東京化成) $0.5 \mathrm{ml}$ ，トリスイミ ダゾールバッファ (0.15M, pH 7.9) 0.5mlを加 兄，室温にて 15 分放置後 $20 \mathrm{mg} / \mathrm{ml} オ リ ン$ (Acid Washed; Fisher Scientific社) 0.5mlにてPKを活 性化し，そのアミダーゼ活性を測定した。

高分子キニノゲン（\%) (high molecular weight kininogen; HMWK) はUchida and Katoriの方法 によつだ、ただ正常血浆を100\%とした。

第证因子様抗原（\%)(VIIAGN) およびC1インヒ ビター (mg/dI) (Cl INH) はそれぞれHoechst社 製抗血清を用い，口ケット免疫電気泳動法によつ た.

アンチトロンビンIII (mg/dl) (ATIII)， $\alpha_{2}$ マクロ グロブリン (mg/dl) ( $\left.\alpha_{2}-\mathrm{MG}\right)$ についてはHoechst 社製免疫拡散板 $\mathbf{M}$ パルチゲンを用いた。

連続希釈硫酸プロタミン試験 $(\times 5, \times 10, \times$ $20, \cdots)$ (serial dilution protamine sulfate test; SDPS）は，Dade社製SDPSキットを用いた。

エタノールダル化試験 (十or-) (EG) はSanfelippo法によつた .

FDP $(\mu \mathrm{g} / \mathrm{ml})$ はラテックス凝集法を利用した Welleome社製キットを用いた。

$\mathrm{HMWFC}(\mu \mathrm{g} / \mathrm{ml})$ はカラムクロマトグラフィ 法によつた ${ }^{6)}$.

尿毒症の程度判定のためBUN，クレアチニン，

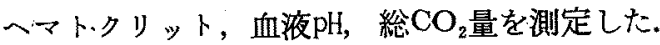

得られたデータはStudent’s $\mathrm{t}$ テストによつて統 計処理した。

\section{II. 結 果}

\section{1）臨床検査成繶}

尿毒症の示標としてはHDCRFに比し， nonHDCRFに扑ける ア.シドーシスの強さが顕著で あつた、へマトクリット值，クレアチニン值には 
Table 1. Clinical data of non-HDCRF and HDCRF.

\begin{tabular}{|c|c|c|c|c|c|}
\hline & (mig/d1) & $\begin{array}{c}\text { creatinine } \\
(\operatorname{mg} / d \mathrm{~d} 1)\end{array}$ & hematocrit & pH & $\begin{array}{l}\text { Totalco } \\
\text { TmM }\end{array}$ \\
\hline non $\mathrm{HDCRP}$ & $\begin{array}{c}105+27 \\
\text { (meandso) }\end{array}$ & $12.2 \pm 3.9$ & $20.5 \pm 4.8$ & $7.28 \pm 0.06$ & $14.1 \pm 3.6$ \\
\hline HPCRF & $90 \pm 12$ & $14.6 \pm 2.7$ & $22.9 \pm 5.3$ & $7.37 \pm 0.03$ & $21.1 \pm 1.9$ \\
\hline $\begin{array}{l}\text { P value } \\
\text { (non HDCRP } \\
\text { vo } \\
\text { HDCRF) }\end{array}$ & $<0.05$ & $>0.05$ & $>0.05$ & $<0.001$ & $<0.002$ \\
\hline
\end{tabular}

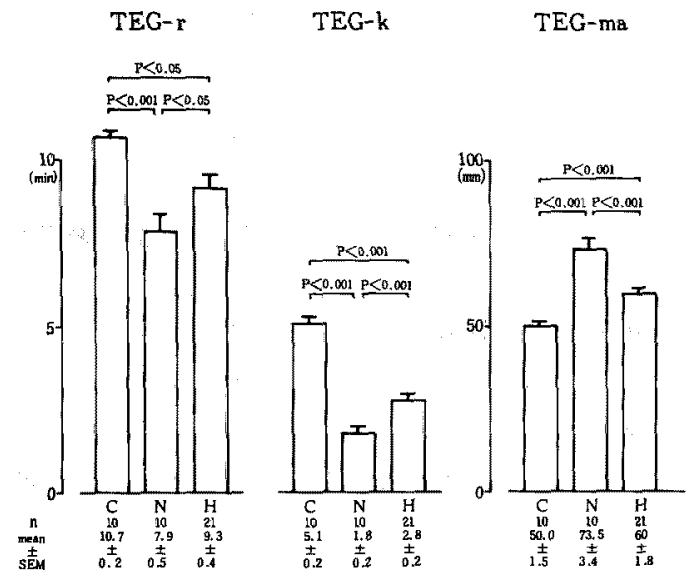

Fig 1. TEG in chronic renal failure.

$\mathrm{C}$ : controls

$\mathrm{N}$ : non-hemodialyzed chronic renal failure

$\mathbf{H}$ : hemodialyzed chronic renal failure

$\mathbf{n}$ : number, SEM : standard error of the mean
PT

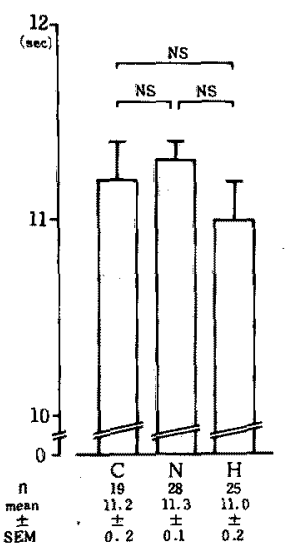

APTT

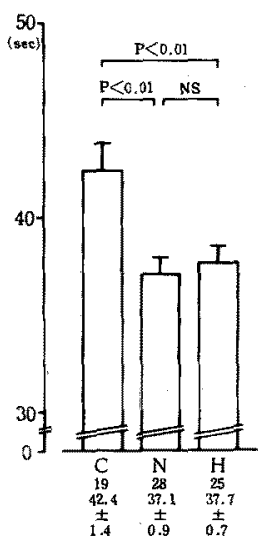

Fig 2. PT and APTT in chronic renal failure. NS : not significant

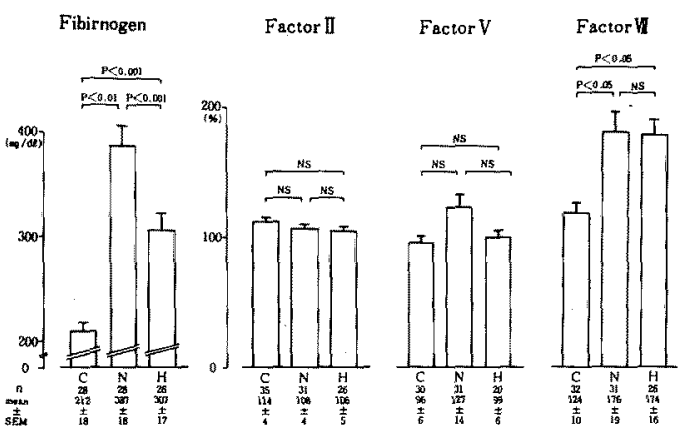

Fig 3. Extrinsic and common pathway of coagulation system in chronic renal failure.

有意差はなかつた，BUNは軽度ではあるがnon HDCRFで有意に高值であつた（表 1 ）。

\section{2）凝固能検査成績}

全血法によるTEGでは図 1 に示すごとく，nonHDCRFではr，k，maいずれも対照群に比し著 しい凝固充進の所見を示した. HDCRFではnonHDCRFに比しかなりの改善を認めるが，正常に までは回復しなかつた。

PT，APTTの結果を図2に示す，PTはnonHCCRF，HDCRF とも対照群との間に有意差はな からた. APTTはnon-HDCRF, HDCRFとも正常 対照群に比し有意に短縮していた。 non-HDCRF でより短縮傾向 の強いことがうかがわれたが， HDCRFとの差は有意ではなかつた。

Fbg，F II，F V，F VIIの結果を図3に示守. non-HDCRF，HDCRF と対照群に比しFbgの著 明な堌加を認め，non-HDCRAではHDCRF と比較 しても有意に増加していた。

F II はnon-HDCRF，HDCRF と当対照群に比し 有意の変動は認められなかつた。

FVKついては，non-HDCRFでは対照群に比 し增加傾向を認めたが有意ではなかつた。 nonHDCRF，HDCRF間にも有意の差は認められなが つた.

F VII変動幅が大きかつたが, 全体的に高值で non-HDCRF，HDCRF とも対照群に比し有意の堌 加を認めた，non-HDCRF，HDCRF間には有意の 


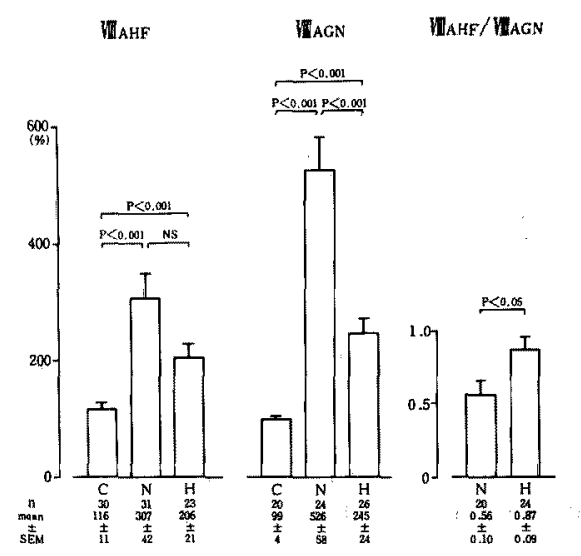

Fig 4. VIIAHF and VIIAGN in chronic renal failure.

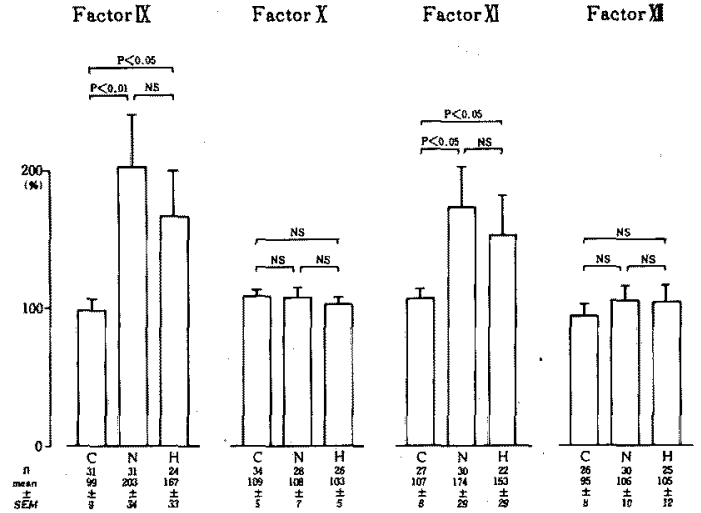

Fig 5. Intrinsic pathway of coagulation system in chronic renal failure.

差は認めなかつた。

図 4 に示すごとく，VIIIAHFの増加は著明で特 にnon-HDCRFで高値を示するのが多く認められ た、non-HDCRFはHDCRFに比較しても有意に高 值であつた。その抗原量VIIAGNの増加はさらに顕 著で，対照群が 比較的狭い範囲内に集中してい るのに比較し，きわめて高值のものが多く，nonHDCRFではその平均は実に $526 \%$ に達した。 こ れはHDCRF と比較しても有意に高值であつた。 またVIIAHFとVIIIAGNの比をみると正常值は1であ るが，non-HDCRFの方がHDCRFより有意に低 く, non-HDCRF の平均は0.56であつた。

F IX，FX，FXI，FXIの結果を図 5 に示す。

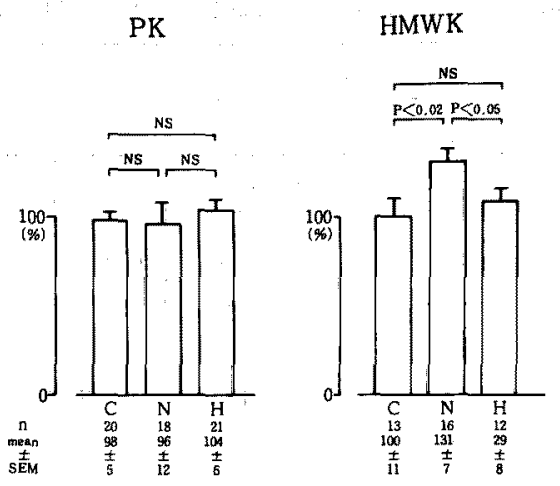

Fig 6. PK and HMWK in chronic renal failure.

F IXは正常範囲にあるものる多い反面，著明に 高い例も少なくなく，全体的にはnon-HDCRF， HDCRF とも対照群に 比乙有意の増加を認めた。 nion-HDCRF とHDCRFの間には有意の差は認めら れなからた。

F Xはnon-HDCRF，HDCRF とむ対照群 との間 に有意の差を認めなかつた.

F XIはF IX と同様の傾向すなわち正常範囲内に あるものる多い反面, 著明な高值を示す例も少な からずあり，non-HDCRF，HDCRF と対照群よ り有意に高值であつた。 non-HDCRF，HDCRF間 には有意の差は認めなかつた。

F XIInon-HDCRF，HDCRF とも対照群との間 に有意の差を認めなかつた。

図6にPK，HMWKの結果を示すＰははnonHDCRFで低い例が何例かみられたが，変動幅 が大きく対照群との間に有意差はなかつた。 HDCRF b対照群との間に有意差は認められなか つた.

HMWKはnon-HDCRFで 正常対照群，HDCRF に比し有意に増加していた。

\section{3）凝固阻止物質}

AT III はnon-HDCRF，HDCRF とす対照群に比し 低下傾向が認められたが，有意ではなかつた。

$\alpha_{2}$ MGはnon-HDCRFで軽度ながら対照群に比し 有意の增加を認めた。 non-HDCRF，HDCRF間に は有意差は認められなかった。 


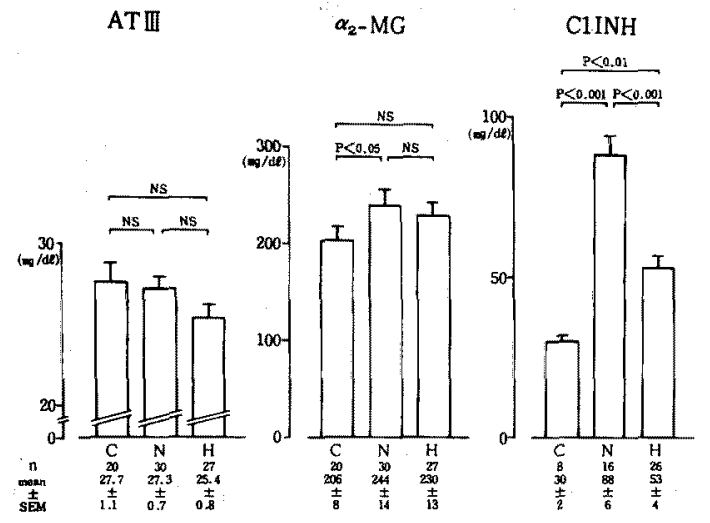

Fig 7. Inhibitors of coagulation system in chronic renal failure.
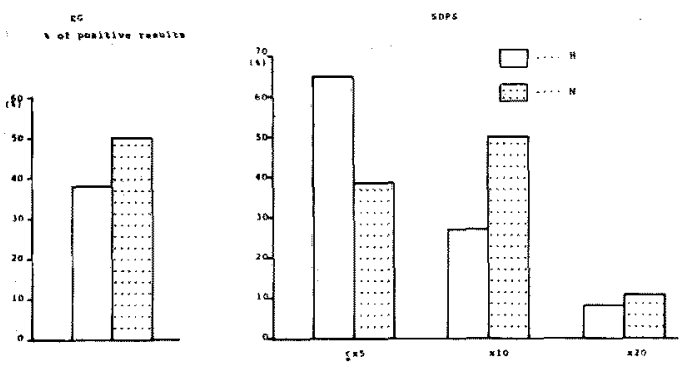

Fig 8. Paracoagulation in chronic renal failure.

ClINHはnon-HDCRF，HDCRF とも対照群より 著明に增加していたが，non-HDCRFの㤝らがよ り䫤著な増加を示した（図7）。

\section{4) 凝固産物}

SDPS，EGの結果を図８亿示す，両者とも高い 陽性率を示したが，non-HDCRFでその傾向がよ り顕著であつた。なお，SDPS，EGの結果は必ず しる一致しなかつた.

図 9 に示すごとくFDPはnon-HDCRF, HDCRF ともに対照群に比し有意の増加を認め, nonHDCRFではHDCRFと比較しても有意の増加を 認めた。

HMWFCはnon-HDCRF，HDCRF とも対照群に 比し軽度ないし中等度の増加を認めた。 nonHDCRFではより高い傾向がらかがわれたが，そ の差は有意ではなかつた（図10）.
FDP

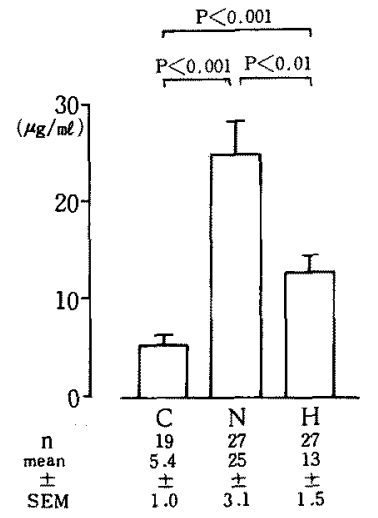

Fig 9. FDP in chronic renal failure.

HMWFC

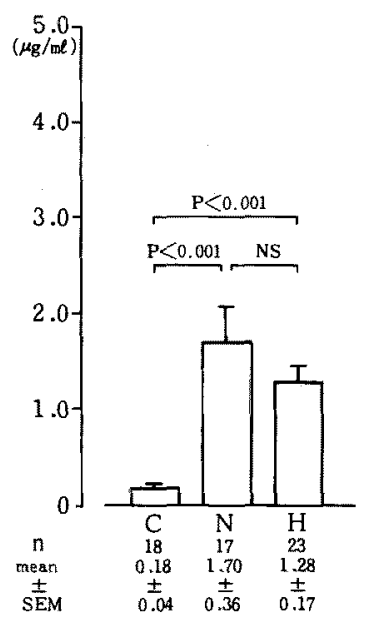

Fig 10. HMWFC in chronic renal failure.

\section{III. 考 案}

今回著者は腎原発性疾患に上る慢性腎不全の血 液凝固能を検討した，non-HDCRFとHDCRFの 2 群について比較検討したが，それは尿毒症その ものの血液凝固能に及ぼす影響と，透析によるホ メオスターシスの部分的改善が凝固能にいかに反 映されるかを観察するためであつた。凝固，凝固 阻止，凝固産物の三つの面から分析した。

non-HDCRFにおいてAPTTが短縮していたが， 
この反応系では充分量の血小板第 3 母子代用物質 が加えられているため，血小板第 3 因子能が低下 しているといわれる慢性腎不全においては，その 評価は慎重でなければならない，その点，全血法 によるTEGは血小板第 3 因子も含めた全血の凝固 過程をより生体に近い状態で，またある程度分析 的にもとらえることが可能である7 . non-HDCRF では $\mathrm{r} ， \mathrm{k}$ とも著明に短縮し，maの增加も著明て あり，典型的な凝固立進の所見である。 またnon一 HDCRFに高頻度にみられた階段現像も凝固六進 時に認められるとのことである ${ }^{8)}$ ，全血での検査 であるためへマトクリットの影響をらけ，人マト クリット値の低い場合凝固穴進のパターンに似る といわ扎。しかしnon-HDCRFとHDCRFとの間 にはへマトクリット值には有意の差は認められな かつたが，r，k，maにはいずれむ有意の差を認め ており，non-HDCRFのTEGパターンは凝固立進 状態の反映と考学てょいと思われる.

またnon-HDCRFではFbg，VIIVHF，VIIAGNが対照 群より著明に増加し，F VII，F IX，F XI，HMWK についても明らかな有意の増加を認めた。このう ちFbg, VIIIAHF, VIIAGNはacute phase reactantsとい われ，体たんぱくの崩壊するような病態において 産生の増加する糖たんぱくの一群に属する ${ }^{9)}$ 末末 期堅不全に扣いては異化光進のためにたんぱく， 窒素平衡が負となり，代謝産物の体内蓄積がみら れ全身蔵器障害をきたすので，このようなacute phase reactantsの増加は当然とい克よう。すた文 献的にも腎不全に括いて Fbg，䜣AHF，VIIIAGNが増

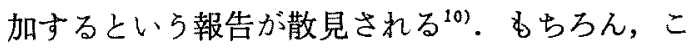
のよらな反応性増加だけでなく，たとえばVIIAGN は血管内皮損傷時に著しく増加するといわれ， Fbgに関しても慢性的な血管凝固症候群では消費 を上回る産生の増加があるといわれている，尿毒 症に推いてもいろいろな要因が複合して増加して いると考光られる.

次に F V，F VII，F IX，F XIの増加についてて あるが，これらの因子活性の増加が物質としての 濃度增加によつてもたらされたものか，それとも
1 分子あたりの活性が増強したためのるのかとい うことが問題となる，というのは，1 段階法によ る測定では F VII, VIIAHF，FIX，F XIは活性化さ れた F Xの作用をらけると 1 分子あたりの活性が 増強するといわれる(1) - 13)。 また，F V，F VII， VIIIAHFはやはり微量のトロンビンの作用をらける と，その活性が増強する(1) 13)。 さらにF VII, F IXは血浆がガラス面と接触すると，その活性が 増強するといわれる いつて一夜 $4{ }^{\circ} \mathrm{C} て ゙$ 放置するとその活性を増強する ことが知られているが，この現象はPKが先天的 に久損している患者血酱ではみられないことか ら，このF VIIの活性増強には血呇カリクレインが 関与するといわれている15). したがつて何らかの 原因により凝固活性化のひきがねがひかれ，流血 中にトロンビン，活性化 F X, 血浆カリ:クレン のようなすでに活性化された凝固因子が存在する 場合， F V ，F VII，VIIIAHF，F IX，F XIが一部既 に活性化されて存在し，活性測定に際して高檤を 示す可能性むありうる. 採血の過程で活性化され る可能性もあるが，同様の採血法で行なつた対照 群ではそのよらな異常值は認められておらず，や はり生体内でのできごとを反映していると考えら れる。なお，2段法に上る測定ではこのような現 象はないが，これは測定操作の途中で活性堌強を きたした凝固因子が吸着剤に吸着されるためであ るといわれる．したがつて，2段法では前駆物質 のみを測定するので，むしろ活性低下といら結果 になることあある．今回は1段法による測定のみ で，抗原量すVIIAGM以外は測定していないので断 定的なことはいえないが，ビタミンK依存性の凝 固因子である F II ，F VII，F IX，F Xのうちこの ような活性增強の現象が認められない $\mathrm{F} I ， \mathrm{~F} \mathrm{X}$ が，対照群との間に有意差がないこと，正常範囲 にあるるのる多い反面，著明な高值を示するのが あることなどから，F VII，F IXの因子活性の増加 は流血中に何らかの原因により産生された活性化 F X，トロンビンなどが存在するために扣こつた 現象と考えるのが自然と思われる.したがつて， 
F VII増加はかならずしも外因系凝固機序の活性 化を示すむのではなく，血頮カリクレインや活性 化 F Xの作用の結果である可能性が大である.

PK, HMWKは元来, 組織のカリクレイン・キ ニン系に対し，血浆のそれを構成する物質として 知られていたが，近年，その先天的欠損患者にお いてAPTTが著明に延長することから新たに接触 相任位置する凝固因子として注目をあびているも のである.PKはnon-HDCRFで対照群に比しバラ ッキが大きく，またHMWKは有意に対照群より 増加して和り， non-HDCRFに打ける接触相の活 性化が示唆された、VIIIAGNの著明な高値からも示 されるように，non-HDCRFに打いては血管内皮 損傷か強く示唆され，その損傷部位で内因系凝固 の接触活性化がおこることは充分化考兵られるこ とである.

凝固に対し阻止的に働くもので，今回検討した のはAT III， $\alpha_{2} \mathrm{MG}, \mathrm{CIINHであつた.} \mathrm{AT} \mathrm{IIIは}$ つとも重要なアンチトロンビンであり， $\alpha_{2} \mathrm{MG}$ 非特異的プロテアーゼインヒビターとしてトロン ビンを阻害する，non-HDCRFではAT IIIは若下低 下傾向を認めるものの有意ではなく， $\alpha_{2} \mathrm{MG}$ 軽 度增加していた，したがつて総合的アンチトロン ビン作用としては正常人とほとんど差はないと考 えられる。一方，C1INHは主として接触相に働く 阻止物質であるが，non-HDCRF，HDCRFとも著 明に增加していた。これはFbgなどと同様，この 物質がacute phase reactantsの一つであるためで あろう。るちろん接触活性化に対する反応として 現われた現象であることも否定できない。

さて, 以上の上らな内因系, 外因系の凝固因子 の活性増加は, 最終的にはフィブリンの形成に至 らなければ真の凝固元進とはいいがたい．このフ ィブリン形成に関する分析のためにとつた方法 は, SDPS, EG, FDP, HMWFCであつた. SDPS, $\mathrm{EG}$ 可溶性フィブリンモノマーの硫酸プロタミ ン, エタノールによるパラコアグレーションを利 用したものである。 EGはFbgが高値の場合偽陽 性を呈するといわれる ${ }^{16)}$ が，SDPSはフィプリン
モノマー，早期FDPにのみ感受性があるといわ れ，最近は臨床的にはフィブリンモノマーの検出 にはもつばらこのSDPSが使用される. 半定量で あるため詳練な分析には向かない，FDPは凝固に ひきつづき扢こる二次線溶によつて出現するるの で，一次線溶によつても血中に增加する点，箃密 な意味での凝固の示標としては疑問がある.これ に対しHMWFCはFbgがフィブリンあるいはその 分解産物と結合し，より高分子となつたものをカ ラムクロマトグラフィーにて分離定量するるので ある. in vitroでは血浆に微量のトロンビンを加 えると增加するが，プラスミンでは增加しない。 その出現時間ははやく，消失もはやいことから HMWFCは血管内凝固の鋭敏かつ特異的示標々 して有用と考えられる ${ }^{17)}$. non-HDCRFではSDPS， EGの陽性率が高く，FDPも增加しており，血管 内フィブリン形成の可能性が強く示唆された。 そ こでょり直接的な証明といらことでHMWFCを 測定したところ，軽度ないし中等度に増加してい た.これはnon-HDCRFに招いては，軽度ながら たえず血管内凝固のおこつていることの一つの証 明と考えられる. 一方, HDCRFではnon-HDCRF にみられる凝固能の六進が全般的に改善されてい た. 症例によつては完全に正常のものもみられ t.

さて， non-HDCRF，HDCRFのこのような凝固 六進状態はいかなる機序によりおこるのであろう か. 凝固因子がいくら増加しても凝固のひきがね がひかれなければ，フィブリンの形成はおこらな い. 生体内に生じるる凝固のひきがね因子として は組織の崩澴，血液有形成分の破壊などによるト ロンボプラスチンの流血中への出現, 免疫複合 体, 血管内皮損傷による内因系凝固の活性化, 血 小板第 3 因子の放出などが考えられる.しかし， 尿毒症では著明な血小板機能障害があり，このよ らな血小板が凝固能立進の原因となるとは考えに くい.また組織の崩壊は機械的な損傷と異なり, 血管の断裂はなく，したがつて，組織トロンボプ ラスチンの血中への流入は困難である. 赤血球寿 
命の短縮も軽度で，これも主たる原因とは考えら れない，また尿毒症のこのような凝固六進所見は 多のう胞腎，腎監炎の上うな免疫学的機序を介 さない原疾患に上る腎不全にも一様に認められる ので免疫複合体に上る可能性も低い，一方，尿毒 症に括ける代謝性アシドーシスが，血管内皮の代 謝に及ぼす影響には無視しえないものがあると考 えられる、系管内皮細胞に対して毒性を有 する未知の毒素（toxin）の影響も考えられる。 なぜならば，血液pHの低下は細胞内酵素の活性を 低下させるであろうし，uremic toxinsのなかには 細胞毒性の強い分画もあるといわれる. Yamada and Nakagawa ${ }^{18)}$ はラット肝細胞を透析時の限外 沪液で組織培養した結果，比較的低分子量の分 画に細胞毒性の強い物質が含まれていることを示 した.これらの毒性が血管内皮細胞に働くとすれ ば，これが内皮細胞の脱落をまねき，組織トロン ボプラスチンの放出, 内因系凝固の接触活性化を ひき抏こすことは充分に考兄られる。白かか慢 性腎不全では高脂血症, 高血圧症, 高尿酸血症, 二次性副甲状腺機能六進症などが高頻度にみられ るが，これらる血管障害の大きな要因になるるの と考学られる，このような血管内皮損傷を裏付け る一つの傍証として，第四因子の特異な動態があ る、VIIIAGN血管内皮細胞と骨髄の巨核球内で合 成されることが知られている 位は現在のところ不明である。したがつて，血管 内皮が損傷をうけた場合，VIIAGNの増加，VIIIAHF/ VIIAGNの低下がみられ，これらは血管内皮障害の 良い示標であるともいわれる ${ }^{20)}$. non-HDCRFで はVIIIAGNは526士285\%ときわわて高值であつた。

また，VIIAHF/VIIAGs 60.56士0.45と低下してい た。さらにnon-HDCRFに抢けるPK值のバラッ キ，HMWKの增加， CIINHの著明な增加などは 内因系凝固の接触活性化を強く示唆するすのであ る.これらの事実から直ちに尿毒症 $\rightarrow$ 血管内皮損 傷 凝固活性化のパターンを証明しえたとするの は危険であり，今後血管壁の形態学的面からの検 討なども行なわなければならないが，一つの仮説
としては一応矛盾のないむのと考えられる。

\section{IV. 結 論}

Non-HDCRF，HDCRFの血液凝固能を検討し， 次の結論をえた。

1） non-HDCRFに括いてはAPTT, TEG-r, kの 短縮, TEG-ma, Fbg, F II , F VII, VIIAHF, VIIAGN, F IX， FXI，HMWKの増加，VIIAHF/VIIAGNの低 下を認めた，それらを反映してフィプリン形成の 示標であるパラコアグレーションの高い陽性率, FDPおよびHMWFCの増加を認めた。

2）HDCRFでは凝固能の改善を認めたが，完 全な回復はえられなかつた。

3）凝固能六進の原因としては，VIIIAGN，VIIAHF/ VIIIAGN，PK，HMWKの動きなどから判断し，代 謝性アシドーシス, uremic toxinsの蓄積などにす とつくと思われる血管内皮損傷が示唆された。

謝辞ご協力いただいた横須賀共済病院 笹岡拓雄 人工蜸臓室長，金山正明内科部長はじめ諸先生，血液 㭘查室 鈴木節子主任，HMWK測定についてこ指導 下さった北里大学薬理学教室 内田泰先生に深謝いた します。

\section{文献}

1) Egeberg $O$ : Blood coagulation in renal failure. Scand J Clin Lab Invest 14: 163, 1962.

2) 佐竹清人：腎之血液凝固.日血会誌 $26: 767$, 1964.

3) Svendsen L, et al: Synthetic chromogenic substrates for determination of trypsin, thrombin and thrombin-like enzymes. Thromb Res $1: 267,1972$.

4) Uchida $Y$ and Katori $M$ : Differential assay method for high molecular weight and low molecular weight kininogens. Thromb Res 15: 127, 1979.

5) Sanfelippo $\mathrm{MJ}$, et al: Protamine sulfate test for fibrin monomers. Amer J Clin Pathol 56: $166,1971$.

6)鉿木節子, 松井則明：高分子フィブリノーダン およびフィブリンの複合体 (HMWFC) にっ いて。I. 測定法の検討。臨床血液 20:901, 1979.

7）坪倉篤堆: Thrombelastograph からみた血液凝 固黑常. 臨床病理 $19: 544,1971$.

8）坪倉篤雄：トロンボェラストグラムによる血 液凝固異常診断の基碟。臨床科学 9：653, 
1973.

9) Brozovic $M$ : Physiolosical mechanisms in coagulation and fibrinolysis. Brit Med Bull $33: 231,1977$.

10) Kazatchkine $M$, et al: Bleeding in renal failure. Brit Med J ii: 612, 1976.

11) Niemetz J and Nossel HL: Activated coagulation factors: In vivo and in vitro studies. Brit J Haematol 16: 337, 1969.

12) Radcliffe $R$ and Nemerson $Y$ : Activation and control of factor VII by activated factor $\mathrm{X}$ and thrombin. J Biol Chem 250: 388, 1975.

13) Bennett B: Coagulation pathway: Interrelationships and control mechanisms. Semin Hematol 14: 301, 1977.

14) Rapaport SI, et al: The effect of glass upon the activity of the various plasma clotting factors. J Clin Invest 34: 9, 1955.

15) Saito $H$ and Ratnoff OD: Alteration of factor VII activity by activated Fletcher factor (a plasma kallikrein): A potential link between the intrinsic and extrinsic blood clotting systems. J Lab Clin Med 85: 405, 1975.

16) Gurewich V, et al: A comparative studies of precipitaiton and paracoagulation by protamine sulfate and ethanol gelation tests. Thromb Res 2: 539, 1973.

17) Alkjaesig NK, et al: Pathophysiological response of the blood coagulation system in acute glomerulonephritis. Kidney Int 10:319, 1976.

18) Yamada $T$ and Nakagawa $S$ : Analyses of uremic ultrafiltrate: A possible coincidence of highly toxic small molecular fraction with guanidine derivatives. Trans Amer Soc Artif Int Organs 22: 155, 1976.

19) Nachman $R$, et al: Synthesis of factor VIII antigen by cultured guinea pig megakaryocytes. J Clin Invest 60: 914, 1977.

20) Boneu B, et al: Factor VIII complex and endothelial damage. Lancet 1: 1430, 1975. 